\title{
Characteristics of Curds With Milk Clotting Enzyme from Indonesian Local Isolate of Lactic Acid Bacteria
}

\author{
Wendry Setiyadi Putranto ${ }^{1}$, Apon Zaenal Mustopa ${ }^{2}$, Jendri Mamangkey ${ }^{3}$, Netty Jojor \\ Aritonang ${ }^{4}$ \\ ${ }^{1}$ Faculty of Animal Husbandry, Universitas Padjadjaran, Jatinangor 45363, Indonesia \\ ${ }^{2}$ Biotechnology Research Center, Indonesia Institute of Science, Jl. Raya Bogor Km. 46, \\ Cibinong, West Java 16911, Indonesia \\ ${ }^{3}$ Department of Biology, Faculty of Mathematics and Natural Sciences, Universitas Sumatera \\ Utara, Indonesia \\ ${ }^{4}$ Health Polytechnic of Health Department, Medan, Indonesia \\ * Corresponding author: \\ Email: wendry@unpad.ac.id
}

\begin{abstract}
.
To get the potential of lalcat acid bacteria isolate to produce Milk Clotting Enzyme (MCE), it is necessary to screen milk clotting activity both quantitatively and qualitatively. Through qualitative observation, the characteristics of the curd resulting from enzyme activity can be obtained. MCE is a protease that has the characteristics of milking. Based on the results of this observational research, the curd characteristic produced can be used as a benchmark to determine the length of time of fermentation and optimization of the determination of ammonium sulfate precipitation concentration. Isolate BAL shows the results of a compact curd at a fermentation time of 25 hours at $37^{\circ} \mathrm{C}$ and the optimization results of the deposition of ammonium sulfate which shows the characteristics of a compact curd by $45 \%$ ammonium sulfate.
\end{abstract}

Keywords: curd characteristics, rennin like protease, milk clotting enzyme

\section{INTRODUCTION}

Rennin is an enzyme needed in the process of making cheese. Rennin is able to clot milk by breaking peptide bonds between phenylalanine and methionine $\left(105^{\text {th }}\right.$ to $106^{\text {th }}$ sequences) from casein polypeptides, producing para-k-casein and macropeptides $[9,4]$. The macropeptide produced from the cutting is water soluble, while the casein will settle. Casein instability occurs due to the breaking of the bonds of Phe and Met so that the other casein fraction settles.

There are several proteases produced by some extracellular microbes which have the capability of having milk clotting activity. Protease with milk clotting activity is known as Milk Clotting Enzyme (MCE). Microbes that produce MCE include Mucor pusillus [2], Mucor bacilliformis [6], Mucor circinelloides [3]. 
In an effort to obtain potential bacterial isolates to produce MCE, isolation and screening stages were carried out. Extracellular proteinases excreted by BAL isolates hydrolyze the casein (skim) substrate into smaller pieces of peptides so that they look clear around the bacterial colony. The screening of proteolytic activity used MRSA media which had been added by $3 \%$ skim milk $[10,1,8]$. BAL isolates showed clear zones around the colonies indicating that BAL isolates had the ability to produce extracellular proteases.

To measure enzyme activity, it can be done quantitatively, which is through Milk Clotting Activity (MCA). In MCA testing, the factor that becomes a measure is the clotting speed (t) in second (seconds). If we compare the characteristics of clumping due to the activity of RLP ( $b$ and $c$ ), it is different from clumping caused by acid (a). One Unit (SU) is 1 Soxhlet Unit (SU) = the amount of enzyme needed to coagulate $1 \mathrm{ml}$ of substrate for 40 minutes at $35^{\circ} \mathrm{C}$. Besides that, it can also be done qualitatively by testing the resulting curd characteristics. This study aimed to determine that the characteristics of the curd resulting from the milk coagulation process can be used as a benchmark in determining the fermentation period and optimization of ammonium sulfate to produce MCE from local BAL isolates.

\section{METHODS}

\subsection{BAL Isolate Screening with Proteolytic Activity}

LAB isolation was obtained from Bakasam (beef fermentation) and Etawa goat milk using MRS media so that it was added by $3 \%$ of skim. BAL colonies showed clear zones around the colonies were proteolytic BAL isolates with the ability to excrete extracellular protease enzymes.

\subsection{Screening of MCA Activity using Modified Skim Milk Agar (SMA) \\ Method}

To obtain proteolytic BAL isolates with indication of clotting activity in milk, an observation of of BAL isolates character on MRSA media contained a 3\% skim was conducted. LAB isolates that showed skim digestion in the media were proteolytic BAL isolates which had a casein (skim) clumping activity. Quantification of the ability to agglomerate casein was then screened with a modification of the Skim Milk Agar method by making an agar block.

\subsection{Agar Block Method [12]}

Efforts to quantify the MCA activity on MRSA media were modified using Agar Block media. In preparing media A, potential isolates (positive high school) were cultured evenly (swab) on the respective media (BAL: MRSA) and then was incubated (BAL: $37^{\circ} \mathrm{C}, 24$ hours). Media B prepared was MRSA (BAL) which had been added 
with 2-3 percent substrate (casein) and made a plug hole. A plug was made on Media A that has been overgrown with BAL evenly and was moved to the plug hole on Media B such as installing Block. It was then continued by incubation and measurement of the resulting clear zone or clotting zone $(\mathrm{cm})$.

\subsection{Milk Clotting Activity (MCA) Testing}

LAB isolates with proteolytic activity and clotting zones were selected on the modified high school media and then were tested for MCA activity $(\mathrm{SU} / \mathrm{mL})$ quantification. $\mathrm{LAB}$ isolates were grown in $5 \mathrm{ml}$ MRS broth and incubated at $37^{\circ} \mathrm{C}$ for 24 hours. Then, centrifugation was carried out at a speed of 10,000 g, for 30 minutes, at $4{ }^{\circ} \mathrm{C}$. Supernatant which is crude enzyme was separated in sterile eppendorf and MCA testing [7]. Furthermore, the curd formed was observed. Observation of curd characteristics was derived from: 1) MCE samples used were isolated during the growth of BAL isolates with various fermentation period of 20, 25, 30, 35, 40, 45, and 50. 2) MCE samples from ammonium sulfate precipitation with concentrations of $40 \%$, $45 \%, 50 \%, 55 \%$, and $60 \%$.

\section{RESULT AND DISCUSSION}

\subsection{Characteristics of Screening Skim Milk Agar (SMA)}

The purity of proteolytic BAL isolates which had been confirmed for purity based on microscopic observations, were further cultivated in MRSA containing 3\% skim milk. At the stage of isolation and proteolytic screening, the character of the clotting formation (clotting zone) or precipitation zone around the colony was not obtained yet.
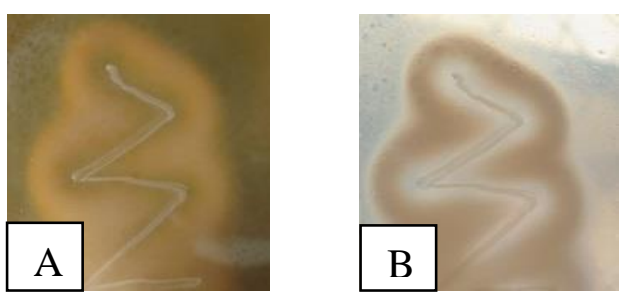

Fig. 1. Isolate LAB at MRSA + skim 3\%. (A) Isolate LAB.1 and LAB. 2

The characteristics of clotting around the LAB colony is an indication that the proteases produced have the ability to agglomerate the skim. Therefore, the indication of the existence of a clotting zone around the LAB colony provides a strong initial indication that the bacterial isolate is capable of producing extracellular proteases which have the activity of agglomerating milk. Furthermore, LAB isolates that showed clotting zone characteristics were further tested to observe these activities with modifications to the SMA (Skim Milk Agar) method. Clotting characteristics of each 
isolate (Figure 1) can be divided into two characters,; (1) Clotting/ precipitating character around the colony and a clear zone pattern formed, and (2) is a character that shows clotting (precipitation) but there is no clear zone formed around the colony.

When we compared it with isolates with high adequate proteolytic activity in yeasts and molds which are able to hydrolyze casein well, it showed a wide clear zone (clear zone) (large) (Figure 2). However, the three isolates in the MCA test did not coagulate the milk (casein). This showed that there were specific microbial isolates that were able to produce MCE.
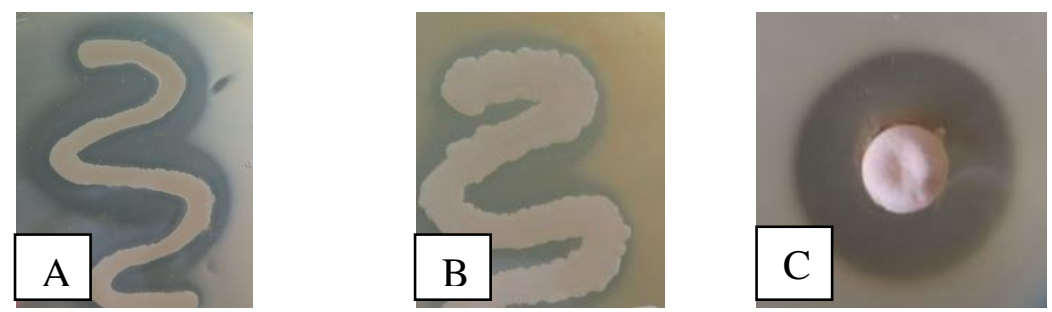

Fig. 2. Extracellular proteolytic activity in Skim Milk Agar (SMA). LAB isolate (A); yeasts isolates (B); mold isolates (C)

High proteolytic activity will hydrolyze casein (skim) completely, so that no casein clumps or a clotting zone were obtained. Therefore, in the initial stages of screening, the clotting characteristics in SMA can be used as an initial indication of the potential of microbial isolates producing MCE.

\subsection{Curd Characteristics on Agar Block}

The SMA method was modified by using Block in order to provide an initial overview of the potential of BAL isolates in producing MCE. The large diameter of the clotting zone gave an indication that the generated MCE had a high clotting activity. Therefore, the modification of this method can be used as an approach in screening the potential for microbes to produce MCE and an early indication of MCA activity. Figure 3 shows that isolate BAL.1. has clumping characteristics around the clotting zone colony with a diameter of $1.5 \mathrm{~cm}$ and clear zone.

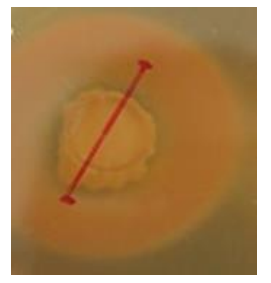

Fig. 3. Curd Characteristics on Agar Block 


\subsection{Characteristics of Curd during Fermentation}

In determining the right fermentation period in MCE production, in addition to the analysis of MCA, PA, and the percentage of curd in this study, qualitative curd characteristics formed are presented in Figure 4. This is a form of confirmation of the results of the generated MCA activity. At the $20^{\text {th }}$ hour visual fermentation, a compact curd or low level of cohesiveness (bad) (+) (1) was not formed yet. However, the curd characteristics with good cohesiveness $(+++)$ were seen at the $25^{\text {th }}$ hour fermentation time (2).
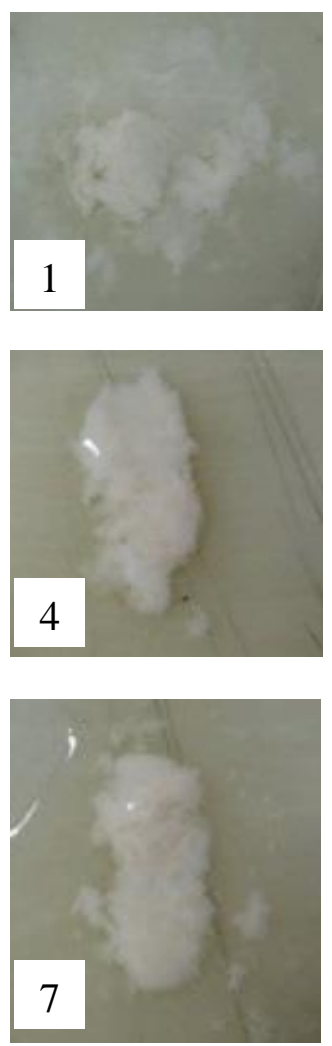
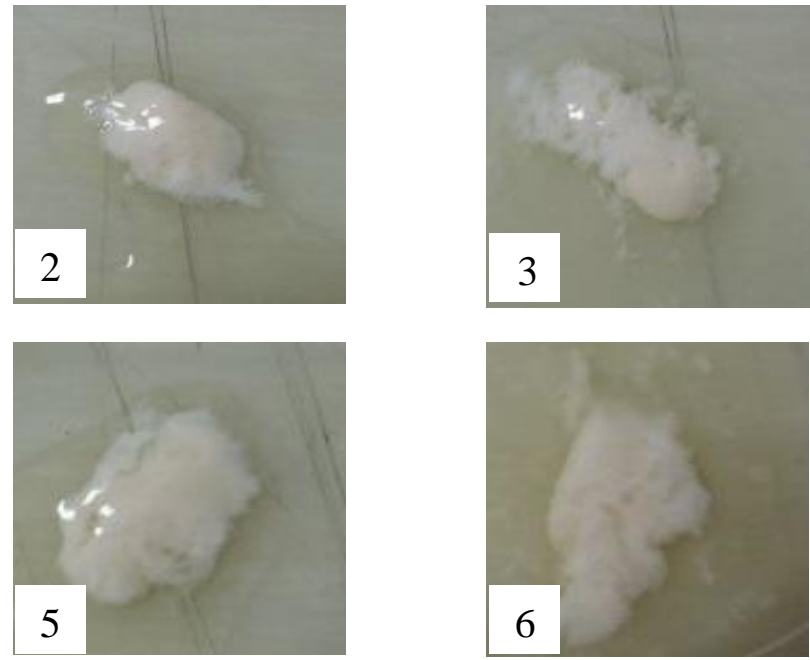

Fig. 4. The curd characteristics that are formed from MCE produced at the time fermentation of Isolate LAB. : 20th hour (1) with low level of curd compactness $(+) ; 25^{\text {th }}$ hour (2) (good: $+++) ; 30^{\text {th }}$ hour (3) (moderate: ++$) ; 35^{\text {th }}$ hour (4) (moderate: ++$) ; 40^{\text {th }}$ hour $(5)$ (moderate: $++), 45^{\text {th }}$ hour (6) (moderate: ++$) ; 50^{\text {th }}$ hour (7) (moderate: ++ ).

The optimization of growth time also shows that the $25^{\text {th }}$ hour is the optimum time to produce MCE. Casein is in the form of casein calcium, which is a complex compound of calcium phosphate and presents in the form of complex colloidal particles called micelles. The casein contained in the raw material has a $\mathrm{pH}$ sensitive 
nature. A decrease in $\mathrm{pH}$ of up to 4.6 will cause casein to become unbalanced and then denaturation will occur. Denatured proteins will decrease their solubility, the hydrophobic inner protein molecule layer turns outward while the hydrophilic outer part folds into folding or reversal occurs at an isoelectric $\mathrm{pH}$ of 4.6-4.7. Eventually, the protein will coagulate and settle, which in turn increases viscosity because the protein molecule expands and becomes asymmetric, so the optical rotation angle of the protein solution will increase as well [11].

\subsection{Characteristics of Curd in Optimization of Precipitated Ammonium Sulfate}

Precipitation using salt is based on the solubility of proteins that interact polar with water molecules, the ionic interactions of proteins with salt, and the repulsion of rejecting proteins with the same charge. Protein solubility (at certain $\mathrm{pH}$ and temperature) increases as the salt concentration increases. An increase in solubility of the protein will increase the strength of the ionic solution. The addition of certain salts will cause protein solubility to decrease (salting out). Water molecules that bind to many salt ions eventually cause the withdrawal of the water casing that surrounds the surface of the protein, thereby causing the proteins to interact, aggregate, and then settle. Ammonium sulfate is the salt most often used to precipitate proteins because it has high solubility in water and is relatively inexpensive [13].

In determining the concentration of the use of ammonium sulfate, the best product also considers the activity of enzyme. In this case, the percentage and characteristics of the curd produced. The curd formed from the use of MCE as a result of the deposition of $45 \%$ ammonium sulfate showed a compact curd characteristic as can be seen in Fig.5.B when compared to the level of use of ammonium sulfate at another level.
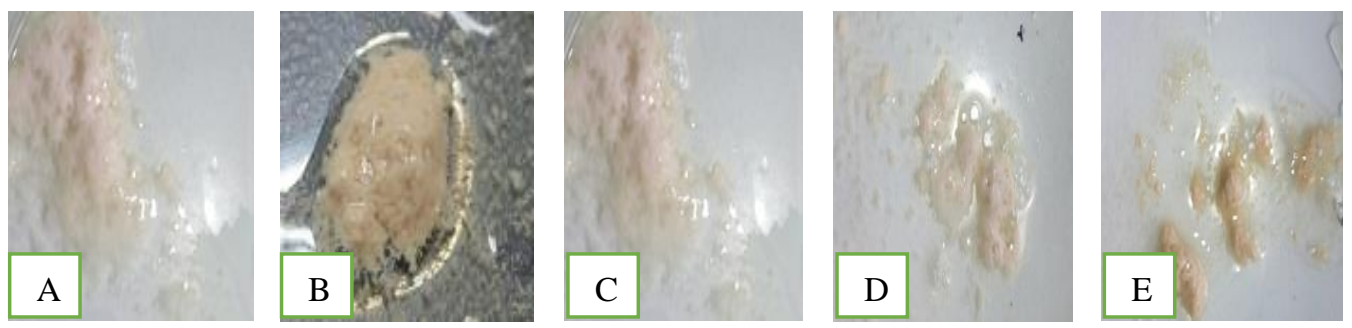

Fig. 5. The characteristics of the curd produced in depositional optimization ammonium sulfate (A) $40 \%$ with compactness level curd (low: +), (B) 45\% (moderate: ++ ), (C) 50\% (low: +), (D) 55\% (low: +) and (E) 60\% (low: +)

The optimization of the use of ammonium sulfate is needed to get the best concentration so that it produces MCE with the highest activity. Ammonium sulfate is a salt that is commonly used because it has several advantages, including high 
solubility in water, relatively inexpensive, and stable protein in a solution of ammonium sulfate (2M - 3M) that lasts for years (Scopes 1987). Purification of MCE produced by Paenibacillus spp.BD3526 using deposition of ammonium sulfate with a concentration of $60 \%$ increased purity by 4.29 times with a yield of $43.02 \%$ [5].

\section{CONCLUSION}

Curd characteristics can be used to determine the fermentation time and optimization of ammonium sulphate loading from MCE isolate BAL.1. MCE was produced in 25 hours, while the $45 \%$ ammonium sulphate concentration resulted in a compact curd characteristic.

\section{ACKNOWLEDGMENTS}

I would like to express my gratitude to Universitas Padjadjaran and LIPI Biotechnology for the assistance so that this research could be carried out.

\section{REFERENCES}

[1] Chi Z, Ma C, Wang P, Li HF. 2007. Optimization of medium and cultivation conditions for alkaline protease production by the marine yeast Aureobasidium pullulans. Biores. Technol. 98: 534-538.

[2] El-Tanboly ES, El-Hofi M, Youssef YB, El-Desoki W. Ismail A .2013. Utilization of salt whey from Egyptian ras (Cephalotyre) cheese in microbial milk clotting enzymes production. Acta Sci. Pol., Technol. Aliment. 12(1) : 9-19.

[3] Fernandez-Lahore HM, Auday RM, Fraile ER, Biscoglio De Jimenes Bonino M,Pirpignan L, Machalinski C and Cascone O.1999. Purification and characterization of an aspartic proteinase from mesophilic Mucor sp. solid state cultures. J Pept Res 53: 599-605.

[4] Fox PF, Guinee TP, Cogan TM, McSweeney PLH. 2000. Fundamentals of cheese science. Aspen Publishers Inc., Gaithersburg, MD

[5] Hang F, Liu P, Wang Q, Han J, Wu Z, Gao C, Liu Z, Zhang H, Chen W.2016.High milk-clotting activity expressed by the newly isolated Paenibacillus spp.strain BD3526. Molecules, 21, 73; doi:10.3390/molecules21010073.

[6] Machalinski C, Pirpignani ML, Marino C, Mantegazza A and de Jiménez Bonino MB.2006.Structural aspect of Mucor bacilliformis proteinase, a new member of the aspartyl-proteinase family. J Biotechnol 123: 443-452.

[7] Otani H., Mitsuhiro I., Akiyoshi H., 1991. The screening of trees having milk activity. Anim. Sci. Tech. 62, 417.

[8] Sindhu R, Suprabha GN, Shashidhar S. 2009. Optimization of process parameters for the production of alkaline protease from Penicillium godlewskii SBSS 25 and its application in detergent industry. Afri. J. Microbiol. Res. 3(9): 515-522. 
International Journal Of Science, Technology \& Management

[9] Suhartono MT.1989.Enzim dan Bioteknologi.Departemen Pendidikan dan Kebudayaan. Direktorat Jendral Pendidikan Tinggi Antar Universitas Bioteknologi IPB. Bogor.

[10] Verma R, Sil K, Pandey AK, Rajak RC. 2001. Solid state fermentation to produce alkaline protease by Aspergillus fumigatus B149. Ind. J. Microbiol. 41: 111-114.

[11] Winarno FG. 1993. Enzim Pangan. PT. Gramedia, Jakarta.

[12] Wendry SP, Roostita LB, Kusmajadi S, Hartati C, Eka W, Andry P, Trianing T, Nanah.2015.Meode Tumpang dan Blok Agar Sebagai Teknik Screening Bakteri Asam Laktat dan Yeasts Isolat Potensial Pangan Fungsional.Prosiding Seminar Nasional Peternakan ke-7.Fakultas Peternakan Univetrsitas Padjadajran.

[13] Scopes RK.1987. Protein Purification Principles and Practice. Edisi ke-2. New York: SpringerVerlag. 